\title{
COMMENTARY
}

\section{Choosing Appropriate Glucagon-like Peptide 1 Receptor Agonists: A Patient-Centered Approach}

Sanjay Kalra

To view enhanced content go to www.diabetestherapy-open.com

Received: January 6, 2014 / Published online: February 19, 2014

(c) The Author(s) 2014. This article is published with open access at Springerlink.com

\section{ABSTRACT}

The individualized treatment of type 2 diabetes mellitus, using various glucagon-like peptide receptor agonists (GLP1RAs), has recently been described. As experience with existing GLP1RAs grows, and as newer molecules in the development pipeline continue to progress, interest related to these drugs continues to grow. This article describes a person-centered approach, using the bio-psychosocial model of health, to help individualized decision making related to choice of GLP1RA. It utilizes an evidence-based approach to discuss various biomedical and psychosocial factors which may influence choice of GLP1RA.

Keywords: Glucagon-like peptide 1 receptor agonists; GLP1RAs; Patient centered; Type 2 diabetes

S. Kalra $(\square)$

Bharti Hospital \& BRIDE, Karnal, India e-mail: brideknl@gmail.com

\section{INTRODUCTION}

Glucagon-like peptide 1 receptor agonists (GLP1RAs) have become an accepted part of the diabetes pharmaco-therapeutic landscape. The GLP1RAs are included in guidelines from various professional bodies such as the International Diabetes Federation (IDF), the American Diabetes Association (ADA), European Association for Study of Diabetes (EASD), and American Association of Clinical Endocrinologists (AACE). GLP1RAs can be used as second-line and third-line agents, in combination with metformin and insulin. There is also evidence to suggest that GLP1RAs should be used earlier on in the natural history of diabetes, so as to utilize their full potential [1].

\section{CLASSIFICATION}

An increasing number of GLP1RAs are available for use, or are in advanced phases of development. While they have earlier been divided according to chemical structure, GLP1RAs can also be classified based on their duration of action (Table 1). This approach makes it easier to compare and contrast the 
Table 1 Glucagon-like peptide 1 receptor agonists (GLP1RA)

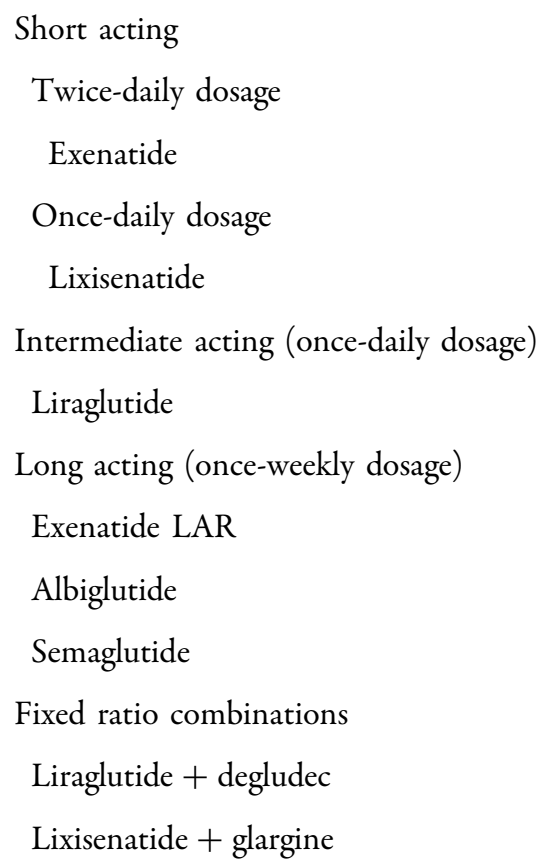

various pharmacokinetic and pharmacodynamic properties of these drugs. Short-acting GLP1RAs are those with a half-life of $<12 \mathrm{~h}$, which requires daily or twice daily administration [2, 3]. Intermediate-acting GLP1RAs are those with a half-life of $>12 \mathrm{~h}$ [4], which allow once daily injection. Long-acting GLP1RAs have half-lives of $>24 \mathrm{~h}[5,6]$ and can be injected as once-weekly doses. The oncedaily GLP1RA, viz, liraglutide and lixisenatide, are also being developed as fixed ratio coformulations with basal insulins, viz, degludec and glargine, respectively.

\section{PROTRACTION OF DURATION OF ACTION}

Various GLP1RAs have been utilizing differing strategies to prolong or protract their duration of action. The shortest-acting GLP1RA, viz exenatide and lixisenatide $[3,7]$, achieve this by exchanging amino acids at the N2 and N3 positions, thus making them resistant to breakdown by dipeptidyl peptidase 4 (DPP4). The renal elimination of the molecule, however, continues as per physiology, and so drug levels fall to baseline prior to the next injection. The short half-life of $2-4 \mathrm{~h}$ means that peak concentrations are maintained for just $6 \mathrm{~h}$.

Liraglutide achieves a longer half-life (12-13 h) and duration of action, by having a fatty acid side chain. This allows it to bind noncovalently to plasma albumin. This increases its size and slows down release of the GLP 1 moiety from plasma albumin, thus prolonging its action [8]. Albiglutide uses a similar albuminbinding based approach, but binds in a covalent manner to the protein. The long half-life of the albumin-GLP1 conjugate allows for a long duration of action and once-weekly administration [5, 9]. Dulaglutide employs a novel mechanism of protraction of action. It conjugates GLP-1 with the Fc fragment of IgG and thus achieves a longer duration of action $[10,11]$. Exenatide long-acting release (LAR) is a chemical modification of exenatide, which is coupled to microspheres that allow slow and steady release of the molecule from its subcutaneous site [6].

\section{PATIENT-CENTERED PHILOSOPHY}

Current guidelines promote a patient-centered approach to the management of diabetes. In essence, a patient-centered approach implies crafting of a management strategy which involves the patient and is respectful of his or her opinion. Viewed through a larger prism, patient-centered care assumes acceptance of the bio-psychosocial model of disease. It is understood that biomedical, psychological, and 
Table 2 Comparison of GLP1RA

\begin{tabular}{|c|c|c|}
\hline & Short-acting GLP1RA & $\begin{array}{l}\text { Intermediate- and long-acting } \\
\text { GLP1RA }\end{array}$ \\
\hline Control of fasting glycemia & Suitable & More suitable \\
\hline Control of postprandial glycemia & More suitable & Suitable \\
\hline Control of HbAlc & Effective & Effective \\
\hline Frequency of dosage & Daily/twice daily & Weekly/once daily \\
\hline Combination with basal insulin & Complementary effect & Complementary effect for liraglutide \\
\hline Combination with premixed insulin & May show beneficial effect & May show complementary effect \\
\hline Use as directly observed therapy (DOT) & Not feasible & Feasible \\
\hline Gauge of needle & Thin $(31 G, 32 G)$ & Thick (23G) for exenatide LAR \\
\hline Injection technique & Simple & $\begin{array}{l}\text { Requires manual dexterity for } \\
\text { exenatide LAR, injection technique } \\
\text { is also simple for liraglutide, titrated } \\
\text { with the same pen }\end{array}$ \\
\hline Injection site reactions & Rare & Common, seldom with liraglutide \\
\hline Gastrointestinal symptoms & More common & Less common \\
\hline Increase in pulse rate & Less common & More common \\
\hline Weight loss & Effective & Effective \\
\hline Improvement in lipid profile & Minimal & Minimal \\
\hline Antibody formation & Relatively high with exenatide & $\begin{array}{l}\text { Relatively high with exenatide LAR; } \\
\text { low for liraglutide }\end{array}$ \\
\hline $\begin{array}{l}\text { Ability to stop in case } \\
\text { of adverse events }\end{array}$ & Retained & Lost for once-weekly injections \\
\hline
\end{tabular}

GLPIRA glucagon-like peptide 1 receptor agonists, $L A R$ long-acting release

social factors impact not only the presentation of diabetes, but also its management. Apart from biological characteristics, psychosocial reality should be taken into consideration while planning a therapeutic regime.

The varieties of GLP1RAs available today and their unique pharmacological properties allow a patient-centered choice to be made in this class of drugs. This is similar to the approach followed while choosing insulins for management of diabetes.

\section{FACTORS INFLUENCING CHOICE OF GLP1RA}

Various factors which influence the choice of a GLP1RA can be categorized according to the bio-psychosocial model (Table 2).

\section{BIOMEDICAL FACTORS}

The biomedical factors which inform the appropriate choice of GLP1RA include efficacy, 
safety, tolerability, and versatility in combination with insulin.

Efficacy is an important determinant choice. The shorter-acting GLP1RAs have a greater effect on postprandial glycemia, while the longer-acting molecules lower fasting glucose to a greater extent. Short-acting GLP1RAs delay gastric emptying, decrease the rate of glucose delivery to the duodenum, blunt postprandial glycemia excursions, and reduce insulin levels as well. They also help in reducing postprandial lipid levels. However, their short duration of action means that optimal glucose control may not be achieved over the full $24 \mathrm{~h}$ [12].

Exenatide lowers breakfast and post-dinner glucose levels to a much greater degree than post-lunch excursions. This is expected with a twice-daily dose, keeping its pharmacokinetic profile in mind. The HbA1c reduction varies from $0.8 \%$ to $1.5 \%$ with the recommended dose of $10 \mu \mathrm{g}$ twice daily [13-16].

Lixisenatide is associated with modest improvements in postprandial glucose after each meal, and in HbA1c (0.7-1.0\%), with a once-daily dose of $20 \mu \mathrm{g}$ [17-19]. This drug has a lower risk of nausea, vomiting and hypoglycemia as compared to exenatide.

The intermediate-acting liraglutide, used in a dose of $1.2-1.8 \mathrm{mg} /$ day, improves both fasting and postprandial glucose values, leading to a $1.1-1.8 \%$ reduction of HbA1c [1, 20-23]. Gastrointestinal effects and hypoglycemia are less common than with exenatide; liraglutide also exhibits added benefits of low antibody formation, reduction in systolic blood pressure, and greater weight loss [24]. The drug is associated with a slight increase in pulse rate, and the impact of this positive chronotropic effect on cardiovascular health is uncertain.

Intermediate- and long-acting GLP1RAs exhibit greater effect on fasting glucose levels, as they continue to act during the nighttime.
They do not have a significant effect on gastric motility, as the initial slowing is abolished due to tachyphylaxis. Shorter-acting GLP1RAs do not suffer from tachyphylaxis because of their intermittent action [3].

The intermediate-acting and long-acting GLP1RAs cover all $24 \mathrm{~h}$ glucose control including fasting glucose. The short-acting GLP1RAs probably also achieve weight loss through central effects mediated via the hypothalamus.

Longer-acting drugs such as albiglutide have a lower HbA1c reduction (0.78\% vs. $0.99 \%)$ and lower body weight reduction $(-0.62$ vs. $-2.21 \mathrm{~kg}$ ) probably because of the larger size which prevents entry into the central nervous system $[25,26]$. The weekly dose of $30 \mathrm{mg}$, facilitated by a long half-life of 6-8 days, is associated with low rates of nausea and hypoglycemia, but significant local injection site reaction [27, 28].

Dulaglutide, too, can be administered once weekly with its half-life of $90 \mathrm{~h}[11,12]$. Significant HbA1c reduction (1.35\%) and weight reduction $(2.43 \mathrm{~kg})$ have been noted with doses of $1 \mathrm{mg}$ once weekly for the first 4 weeks, followed by $2 \mathrm{mg}$ weekly for 12 weeks. Nausea and a positive chronotropic effect are noted with this long-acting GLP1RA.

Injection site reactions such as nodule formation are most often observed with exenatide LAR, which also needs thicker gauge needle for administration [29-32]. While diarrhea occurs more frequently with longeracting compounds, nausea seems to be more common with short-acting GLP1RA. This may be a function of their effect on gastrointestinal motility. Gastroparesis may be an indication to choose intermediate- or longer-acting GLP1RA, while being a relative contraindication for the shorter-acting GLP1RA.

The duration of action of GLP-1 analogs determines the possible combination with a 
short-acting insulin or a basal insulin. The short-acting exenatide can be given with a basal insulin as it has a greater effect on postprandial glucose levels because of its shorter half-life. In contrast, the longer-acting GLP-1 analogs exert greater effect on fasting glucose levels than shorter-acting GLP-1 analogs. Selection of a GLP1RA would depend on which glycaemic disturbance is more predominant [33].

The possible combination of a long-acting GLP-1 analog with a short-acting insulin would also offer the advantages of complementary pharmacologies and could theoretically reduce both fasting and postprandial blood glucose levels.

A positive chronotropic effect has been noted with intermediate- and long-acting GLP1RA, but not with the short-acting molecules. The short-acting drugs are also associated with greater improvements in postprandial lipid excursions: these factors may encourage their use in specific patients with cardiovascular morbidity.

Another biomedical factor which determines the choice of GLP analog prescribed is the effect on autonomic functions. Liraglutide has less effect on gastrointestinal motility than shortacting GLP-1 analogs like exenatide and lixisenatide $[34,35]$. Thus, liraglutide is a better choice in diabetic patients with impaired autonomic functions. On the other hand, exenatide and lixisenatide can be prescribed in patients with no signs and symptoms of gastroparesis.

Thus, careful assessment of the expected efficacy (fasting vs. postprandial vs. overall glycemic control), anticipated risk of side effects (gastrointestinal symptoms, hypoglycemia, antibody formation, injection site reactions), effect on weight, cost and comorbid conditions (dyslipidaemia, hypertension) can help individualize the choice of GLP1RA.

\section{PSYCHOSOCIAL FACTORS}

Psychosocial factors may also influence the choice of a GLP1RA. The ability of the patient to self-inject, to adhere to pre-specified times of injection(30 min before meals for exenatide), manual dexterity, frequency of contact with health-care providers, meal pattern followed, and adherence to therapy are some of these issues.

For a person who can self-inject, all GLP1RAs are equally feasible for use. Use of exenatide LAR, however, requires some amount of manual dexterity, as it has to be self-mixed prior to injection. For those unable or unwilling to selfinject and dependent upon a caregiver for the same, a once-weekly injection of long-acting GLP1RA represents a useful therapeutic strategy. This once-weekly injection can be administered as directly observed therapy (DOT), akin to that used in tuberculosis control programs. This approach has the added advantage of encouraging regular patient provider contact, which facilitates early detection of adverse events and complications, and encourages more efficient lifestyle modification. It is also helpful in patients who may not adhere to more frequently administered therapy.

Meal pattern also informs the choice of a GLP1RA. Patients who consume heavy breakfast and dinner may benefit from exenatide twice daily, while those who take a light dinner may wish to take lixisenatide. Liraglutide's profile is such that it will be effective with all meal patterns. Patients with irregular meal habit and lifestyles, which put them at risk of hypoglycemia, will respond to once-weekly drugs without major safety concerns. 
The different GLP-1 analogs have been compared with respect to the improvement in the quality of life and treatment satisfaction. The increase in patients' treatment satisfaction from baseline is significantly higher with $1.8 \mathrm{mg}$ liraglutide than with sitagliptin, but the increase with $1.2 \mathrm{mg}$ liraglutide versus sitagliptin is not significant [36]. No difference was perceived in the convenience of treatment between the oral versus injectable. Compared to patients on traditional therapy which was insulin, patients taking exenatide showed greater satisfaction, increased well-being and decreased anxiety [37]. Liraglutide $1.8 \mathrm{mg}$ versus glimepiride improves psychological and emotional well-being and health perceptions by reducing anxiety and worry associated with weight gain [38].

\section{CONCLUSION}

The preceding discussion provides a reasonably robust evidence-based assessment upon which an appropriate GLP1RA can be chosen or changed. Further research and experience will help utilize GLP1RA therapy in the best possible manner for the benefit of people with diabetes.

\section{ACKNOWLEDGMENTS}

No funding or sponsorship was received for this study or publication of this article. The author meets the ICMJE criteria for authorship for this manuscript, takes responsibility for the integrity of the work as a whole, and has given final approval for the version to be published.

Conflict of interest. The author declares no conflicts of interest.
Compliance with ethics guidelines. This article does not contain any new studies with human or animal subjects performed by the author.

Open Access. This article is distributed under the terms of the Creative Commons Attribution Noncommercial License which permits any noncommercial use, distribution, and reproduction in any medium, provided the original author(s) and the source are credited.

\section{REFERENCES}

1. Nauck M, Frid A, Hermansen K, Shah NS, Tankova T, Mitha IH, et al. Efficacy and safety comparison of liraglutide, glimepiride, and placebo, all in combination with metformin, in type 2 diabetes: the LEAD (liraglutide effect and action in diabetes)2 study. Diabetes Care. 2009;32:84-90.

2. Fineman MS, Bicsak TA, Shen LZ, Taylor K, Gaines E, Varns A, et al. Effect on glycemic control of exenatide (synthetic exendin-4) additive to existing metformin and/or sulfonylurea treatment in patients with type 2 diabetes. Diabetes Care. 2003;26:2370-7.

3. Werner U, Haschke G, Herling AW, Kramer W. Pharmacological profile of lixisenatide: a new GLP1 receptor agonist for the treatment of type 2 diabetes. Regul Pept. 2010;164:58-64.

4. Degn KB, Juhl CB, Sturis J, Jakobsen G, Brock B, Chandramouli $\mathrm{V}$, et al. One week's treatment with the long-acting glucagon-like peptide 1 derivative liraglutide (NN2211) markedly improves 24-h glycemia and $\alpha$ - and $\beta$-cell function and reduces endogenous glucose release in patients with type 2 diabetes. Diabetes. 2004;53:1187-94.

5. Matthews JE, Stewart MW, De Boever EH, Dobbins RL, Hodge RJ, Walker SE, et al. Pharmacodynamics, pharmacokinetics, safety, and tolerability of albiglutide, a long-acting glucagon-like peptide-1 mimetic, in patients with type 2 diabetes. Clin Endocrinol Metab. 2008;93:4810-7.

6. Kim D, MacConell L, Zhuang D, Kothare PA, Trautmann $M$, Fineman $M$, et al. Effects of onceweekly dosing of a long-acting release formulation of exenatide on glucose control and body weight in subjects with type 2 diabetes. Diabetes Care. 2007;30:1487-93. 
7. Kolterman OG, Buse JB, Fineman MS, Gaines E, Heintz S, Bicsak TA, et al. Synthetic exendin-4 (exenatide) significantly reduces postprandial and fasting plasma glucose in subjects with type 2 diabetes. Clin Endocrinol Metab. 2003;88:3082-9.

8. Knudsen LB, Nielsen PF, Huusfeldt PO, Johansen NL, Madsen K, Pedersen FZ, et al. Potent derivatives of glucagon-like peptide- 1 with pharmacokinetic properties suitable for once daily administration. J Med Chem. 2000;43:1664-9.

9. Bush MA, Matthews JE, De Boever EH, Dobbins RL, Hodge RJ, Walker SE, et al. Safety, tolerability, pharmacodynamics and pharmacokinetics of albiglutide, a long-acting glucagon-like peptide-1 mimetic, in healthy subjects. Diabetes Obes Metab. 2009;11:498-505.

10. Glaesner W, Vick AM, Millican R, Ellis B, Tschang $\mathrm{SH}$, Tian $\mathrm{Y}$, et al. Engineering and characterization of the long-acting glucagon-like peptide- 1 analogue LY2189265, an Fc fusion protein. Diabetes. 2010;26:287-96.

11. Barrington P, Chien JY, Tibaldi F, Showalter HD, Schneck K, Ellis B. LY2189265, a long-acting glucagon-like peptide-1 analogue, showed a dosedependent effect on insulin secretion in healthy subjects. Diabetes Obes Metab. 2011;13:434-8.

12. Buse JB, Rosenstock J, Sesti G, Schmidt WE, Montanya E, Brett JH, et al. Liraglutide once a day versus exenatide twice a day for type 2 diabetes: a 26-week randomised, parallel-group, multinational, open-label trial (LEAD-6). Lancet. 2009;374: 39-47.

13. Kendall DM, Kim DD, Riddle MC, Fineman MS, Rosenstock J, Baron AD, et al. Effects of exenatide (exendin-4) on glycemic control over 30 weeks in patients with type 2 diabetes treated with metformin and a sulfonylurea. Diabetes Care. 2005;28:1083-91.

14. Buse JB, Henry RR, Han J, Kim DD, Fineman MS, Baron $\mathrm{AD}$, et al. Effects of exenatide (exendin-4) on glycemic control over 30 weeks in sulfonylureatreated patients with type 2 diabetes. Diabetes Care. 2004;27:2628-35.

15. Defronzo RA, Ratner RE, Han J, Kim DD, Fineman MS, Baron AD, et al. Effects of exenatide (exendin4) on glycemic control and weight over 30 weeks in metformin-treated patients with type 2 diabetes. Diabetes Care. 2005;28:1092-100.

16. Heine RJ, Van Gaal LF, Johns D, Mihm MJ, Widel $\mathrm{MH}$, Brodows RG, et al. Exenatide versus insulin glargine in patients with suboptimally controlled type 2 diabetes: a randomized trial. Ann Intern Med. 2005;143:559-69.
17. Gerich JE, Fonseca VA, Alvarado-Ruiz R, Raccah D, Zieleniuk I, Boka G, et al. Monotherapy with GLP-1 receptor agonist, lixisenatide, significantly improves glycaemic control in type 2 diabetic patients [abstract 830]. Diabetologia. 2010;53 (Suppl 1):S330.

18. Ratner RE, Saubadu S, Dimaz AL, Aronson R, Miossec P, et al. Efficacy and safety of lixisenatide once-daily versus placebo in patients with type 2 diabetes mellitus insufficiently controlled on sulfonylurea \pm metformin (Get Goal-S.) [abstract 785]. Diabetologia. 2011;54:S317.

19. Rosenstock J, Christensen M. Efficacy and safety of lixisenatide once-daily versus exenatide twice-daily in patients with type 2 diabetes insufficiently controlled on metformin (GetGoal-X) [abstract 786]. Diabetologia. 2011;54:S317.

20. Garber A, Henry R, Ratner R, Garcia-Hernandez PA, Rodriguez-Patti H, Lover-Alvarez I, et al. Liraglutide versus glimepiride monotherapy for type 2 diabetes (LEAD-3 Mono): a randomised, 52-week, phase III, double-blind, parallel-treatment trial. Lancet. 2009;373:473-81.

21. Marre M, Shaw J, Brändle M, Bebakar WM, Kamaruddin NA, Strand J, et al. Liraglutide, a once-daily human GLP-1 analogue, added to a sulphonylurea over 26 weeks produces greater improvements in glycaemic and weight control compared with adding rosiglitazone or placebo in subjects with type 2 diabetes (LEAD-1 SU). Diabet Med. 2009;26:268-78.

22. Zinman B, Gerich J, Buse JB, Lewin A, Schwartz S, Raskin $\mathrm{P}$, et al. Efficacy and safety of the human glucagon-like peptide-1 analog liraglutide in combination with metformin and thiazolidinedione in patients with type 2 diabetes (LEAD-4 Met + TZD). Diabetes Care. 2009;32: 1224-30.

23. Buse JB, Garber A, Rosenstock J, Schmidt WE, Brett $\mathrm{JH}$, Videbæk $\mathrm{N}$, et al. Liraglutide treatment is associated with a low frequency and magnitude of antibody formation with no apparent impact on glycemic response or increased frequency of adverse events: results from the Liraglutide Effect and Action in Diabetes (LEAD) trials. J Clin Endocrinol Metab. 2011;96:1695-702.

24. Astrup A, Rössner S, Van Gaal L, Rissanen A, Niskanen L, Al Hakim M, et al. Effects of liraglutide in the treatment of obesity: a randomised, double-blind, placebo-controlled study. Lancet. 2009;374:1606-16.

25. GSK receives initial data from the first completed phase lll study of albiglutide in type 2 diabetes. GlaxoSmithKline (online); 2011. http://www.gsk. 
com/media/pressreleases/2011/2011-pressrelease742869.htm. Accessed 15 Dec, 2013.

26. Rosenstock J, Reusch J, Bush M, Yang F, Stewart M. The potential of albiglutide, a long-acting GLP-1 receptor agonist, in type 2 diabetes: a randomized controlled trial exploring weekly, biweekly, and monthly dosing [abstract]. Diabetes. 2009;59:163OR.

27. Stewart MW, Reusch JE, Bush MA, Yang F, Rosenstock J. The gastrointestinal adverse event profile of albiglutide, a long-acting GLP-1 receptor agonist, in type 2 diabetes [abstract]. Diabetes. 2009;59:598-P.

28. Umpierrez GE, Blevins T, Rosenstock J, Cheng C, Anderson JH, Bastyr EJ. The effects of LY2189265, a long-acting glucagon-like peptide-1 analogue, in a randomized, placebo-controlled, double-blind study of overweight/obese patients with type 2 diabetes: the EGO study. Diabetes Obes Metab. 2011;13:418-25.

29. Drucker DJ, Buse JB, Taylor K, Kendall DM, Trautmann M, Zhuang D, et al. Exenatide once weekly versus twice daily for the treatment of type 2 diabetes: a randomised, open-label, non-inferiority study. Lancet. 2008;372:1240-50.

30. Diamant M, Van Gaal L, Stranks S, Northrup J, Cao $\mathrm{D}$, Taylor K, et al. Once weekly exenatide compared with insulin glargine titrated to target in patients with type 2 diabetes (DURATION-3): an open-label randomised trial. Lancet. 2010;375:2234-43.

31. Bergenstal RM, Wysham C, Macconell L, Malloy J, Walsh B, Yan P, et al. Efficacy and safety of exenatide once weekly versus sitagliptin or pioglitazone as an adjunct to metformin for treatment of type 2 diabetes (DURATION-2): a randomised trial. Lancet. 2010;376:431-9.

32. Blevins T, Pullman J, Malloy J, Yan P, Taylor K, Schulteis C, et al. DURATION-5: exenatide once weekly resulted in greater improvements in glycemic control compared with exenatide twice daily in patients with type 2 diabetes. J Clin Endocrinol Metab. 2011;96:1301-10.

33. Fineman MS, Cirincione BB, Maggs D, Diamant M. GLP-1 based therapies: differential effects on fasting and postprandial glucose. Diabetes Obes Metab. 2012;14:675-88.

34. Meier JJ. GLP-1 receptor agonists for individualized treatment of type 2 diabetes mellitus. Nat Rev Endocrinol. 2012;8:728-42.

35. Lorenz M, Pfeiffer C, Steinsträßer A, Ruus P. Effects of lixisenatide once daily on gastric emptying and relationship to postprandial glycemia in type 2 diabetes mellitus (Abstract). Diabetes. 2012;61 (Suppl 1):A280.

36. Pratley R, Nauck M, Bailey T, Monataya E, Cudihhy $\mathrm{R}$, Filleti $\mathrm{S}$, et al. One year of liraglutide treatment offers sustained and more effective glycaemic control and weight reduction compared with sitagliptin, both in combination with metformin, in patients with type 2 diabetes: a randomised, parallel-group, open-label trial. Int J Clin Pract. 2011;65:397-407.

37. Grant P, Lipscomb D, Quin J, et al. Psychological and quality of life changes in patients using GLP-1 analogues. J Diabetes Complications. 2011;25: 244-6.

38. Bode BW, Testa MA, Magwire M, Hale PM, Hammer $\mathrm{M}$, Blonde $\mathrm{L}$, et al. Patient reported outcomes with following treatment with human GLP-1 analogue liraglutide or glimiperide in monotherapy: results from a randomised controlled trial in patients with type 2 diabetes. Diabetes Obes Metab. 2010;64: 604-12. 